\title{
The New Wars Thesis and the Yugoslav Conflict: Beyond Empirical Criticisms
}

\author{
Hino, Aya \\ $\mathrm{PhD}$ Candidate/Visiting Tutor, Goldsmiths, University of London \\ 日 野文 \\ （ロンドン大学大学院博士課程・客員講師）
}

\begin{abstract}
The conceptualization of new wars has altered the way in which we comprehend violence, identity, and politics in the post-Cold War era, and reconfigured our conviction of ethics, morality, and 'the political.' In particular, the second implication of the conception of new wars is significant, as that the de novo proposed ethics, morality, and 'the political' de-legitimize the conventional Westphalian mode of understanding modern politics, and offer a possibility of universal cosmopolitan platform, the politics of inclusion, for dealing with violence. This article, from a social constructivist perspective, aims at reconsidering the new wars thesis and more specifically the epistemological problem behind the proposed cosmopolitan solution.

My problematization of new wars thesis brings to the fore the Yugoslav conflict as the main empirical reference point, aiming to reveal the discursive construction of the representation of the conflict as an embodiment of the characteristics of new wars. Any representation is a paradigmatic form of reality and has in itself a representational temporarily. It is because the construction of representation is subject to the circumstances directly transmitted from the past and the circumstances directly influenced by particular spatio-temporal contexts. Therefore, the representational construction of the Yugoslav conflict as an archetype of new war has to be understood as a mode of perceiving the seemingly incomprehensible violence witnessed within the post-Cold War context.

By offering a reading of new wars thesis as a rhetorical paradigm, this article suggests two problems of the thesis and proposed cosmopolitan solution. First, the characterization of the Yugoslav conflict as an archetype of new wars is not particularly helpful to alter the history-long balkanist representation of self/other relationship; instead it has reinforced some negative connotations of Yugoslavia as the other. That is, the thesis transforms mere appearances of the conflict into the essence, which reinforces otherness and inferiority of Yugoslavia. This essentialization constitutes a ground for rationalizing a new 'civilizing' mission of the West under the guise of global civil society with its seemingly universal ethics and morality. Hence, the second problem is that the cosmopolitan solution for new wars is not as inclusive as it proposes itself to be, as that its inclusiveness is dependent upon certain conditions derived from particular western ethics, morality,
\end{abstract}

Keywords: Yugoslavia, the new wars thesis, representation, othering 
and ideal type of how society ought to be instituted. Because ethics, morality, and ideal type of society are not singular but plural conceptions, linking them to the cosmopolitan politics of collective deliberation simply indicates exclusion of something unethical, immoral, and defective from the very politics of cosmopolitan solution. Though 'the political' within the cosmopolitan global civil society might be based on freedom and public deliberation, the antagonistic dichotomies are inherent features of 'the political' of such a global platform. That said, this article concludes that the new wars thesis has effectively constructed another paradigm of representing Yugoslavia, and importantly rearticulated the relative superiority of civic West, by reifying the polarity of heterogeneous domains, such as West and non-West, us and them, civic and ethnic, and ideal and defective.

\section{Introduction}

It is no exaggeration to say that the conceptualization of modern warfare as new wars has altered the way in which we comprehend violence, identity, and politics. Its repercussions go much beyond the mode of our intervention for dealing with wars and the immediacy of its force towards the political circle; the new wars thesis has also played an essential part in reconfiguring our conviction of ethics, morality, and the political ${ }^{(1)}$. Though the former implication surely calls for judgment of its quality, founded upon the social constructivist skepticism about value-free valid knowledge, my concern is primarily placed on the latter. Therefore, this article problematizes the ideal type of ethical, moral and political conviction that manifested itself with the new wars thesis. To this end, Mary Kaldor's version of the conception of new wars should be the primary object of problematization. Although there are several other variants of the conception ${ }^{(2)}$, hers presents, in the most explicit manner, the ideal mode of reconfiguration of our ethical, moral and political conviction, in its introduction of a cosmopolitan solution to new wars. My problematization of Kaldor's new wars thesis brings to the fore the Yugoslav conflict as the main empirical reference point, aiming to reveal the discursive construction of the representation of Yugoslavia as an embodiment of the characteristics of new wars, and the subsequent implication of such a construction to our conviction of ethics, morality and the political. In doing so, the article offers a reading of the new wars thesis as a rhetorical paradigm that reifies the polarity of heterogeneous domains, such as West and non-West, us and them, civic and ethnic, and ideal and defective, and that, in so doing, it provokes a hierarchy between those domains.

(1) 'The political' is described by Heidegger as something having to do with the ontological level, or by Mouffe "the ontological [that] concerns the very way in which society is instituted" (2005, 8-9), whilst 'politics' refers to the set of institutions and practices by which politico-economic and politico-social orders are created, implemented and maintained.

(2) Although Kaldor is apparently the central figure in conceptualizing new wars, other advocates of the conception need to be mentioned. Martin van Creveld (1991) effectively distinguishes modern warfare from the Clausewitzean wars by marking the differences between the two, and the differences include the actors, the relationship between the actors, the strategy and tactics, and the motivations for mobilization. Herfried Munkler (2005, originally published in German in 2002) argues that what constitutes the new-ness of new wars is the asymmetrical nature of the wars, which has derived from the technological advancement and subsequent decline of the state as the preserver of the monopoly over the legitimate use of coercion. Based on van Creveld and Munkler, Andrea J. Drew and Mohamed Mahmoud Ould Mohamedou (2007) focus particularly on the emergence and expansion of terrorist groups as a crucial factor that has changed the modern warfare. 
The first part of this article offers some general considerations about the rhetorical paradigms of representation of Yugoslavia. Maria Todorova's conception of balkanism will be briefly mentioned as one of the most prevalent paradigms, and the question of the self/other relationship will be put forward as the centerpiece for construction of representations. The second part uncovers the rhetorical paradigm of Yugoslav representation manifested throughout the new wars thesis, vis-à-vis summarizing some important conceptual conditions submitted by the thesis, including the limitations of Clausewitzean conception, the failure of 'military humanism,' and the cosmopolitan global civil society as an alternative mode of the political that invariably reconfigures our ethical, moral, and political conviction. The concluding section, however, problematizes the proposed alternative conviction, arguing that both the naming of the Yugoslav conflict as new wars and the seemingly inclusive cosmopolitan solution in fact reinforce a sharp division between the western self and the Yugoslav other, and consequently reintroduce an abstract but essential hierarchy between the two.

\section{The self/other relationship and problematization of the representation of Yugoslavia}

The Yugoslav conflict and dissolution have been interpreted as one of the symbolic moments of transformation in the international political landscape, and the Anglo-American intellectual debate has encompassed many dimensions of the conflict. Given that the new wars thesis, among many conceptions, ideas and comprehensions, has become one of the pivotal definitions of the conflict, it is worth problematizing the thesis itself and questioning what role the external intellectual have played, not in the Yugoslav conflict per se, but in understanding and interpreting the conflict as an archetype of new wars, and what made it possible for them to propose a cosmopolitan global civil society as an appropriate and necessary solution for such a war.

Despite the noticeable heterogeneity of the external intellectual works on the Yugoslav conflict and dissolution, there seems to be a presumption on which the intellectuals draw comprehensive accounts of the conflict and full explanations of its causes. This presumption is embodied intelligibly within a statement of General Philippe Morillon, the UN's commander in Sarajevo. The conflict "is afflicted by a human illness," he said, "fear of others, fear of the other." ${ }^{(3)}$ And in dealing with the fear of others, Bill Clinton noted after the agreement on Dayton Accord, "in Bosnia this terrible war has challenged our interest and troubled our souls"; it was the challenge to longstanding "America's ideals-liberty, democracy and peace." ${ }^{(4)}$ Tony Blair invoked the Holocaust suggesting that "the sprit of the Second World War" reappeared, insomuch as that "onward march of liberation" was not only desirable but also appropriate and justifiable ${ }^{(5)}$. What the above quotes foreground is the Anglo-American tendency, not limited to the intellectuals but also shared within political circles, to characterize the conflict as a challenge to western ideals, which was apparently derived from the fear of atrocity that the West had left in its past. That said, the common presumption of the external intellectuals is, simply put, the

\footnotetext{
(3) Morillon 1993. Cited in David Campbell 1998, ix.

(4) President Clinton's speech on Bosnia (November 27, 1995).

(5) Tony Blair's speech on "Doctrine of the International Community," speech by Tony Blair at the Economic Club, Chicago (April 24, 1999).
} 
otherness of Yugoslavia. It is important to note that, as Campbell justly puts it, "fear of others is not a pathology possessed by others alone, it afflicts 'us' as well. ${ }^{\left({ }^{(6)}\right.}$ Hence, the presumption evokes the question of the Anglo-American relationship to others, and the question of the relative identification of western self.

To be sure, the question of self/other relationship is not explicitly manifested in the works on the Yugoslav conflict— the new wars thesis included—with a few exceptions including Todorova (1994, 1997, 2004), Campbell (1998), and Drapac (2010). However, as the later discussion in this article suggests, the new wars thesis and its cosmopolitan solution are dependent on an epistemological device of othering. Othering is often explained by unveiling political, economic, and cultural relationships between states, societies, or groups of people, which is typically defined in terms of dominance and subordination. It is a process of establishing a material and cognitive dichotomy between self (subject) and other (object). It indicates not only a mere act of categorization according to geography, race, ethnicity, or religion, but also represents the power of the subject to carry out such an act, and to produce knowledge of the object. To this end, practices of othering are expanded to the level of consciousness, enabling the subject's self-identification as being different from, or even superior to, its object. Foregrounding the question of self/other relationship as the point of departure for problematizing the debate over the Yugoslav conflict entails that Yugoslavia has in itself immaterial meanings, which are constructed through othering by the outsiders, and which extend its scope much beyond its geography ${ }^{(7)}$. The Anglo-American intellectuals do not, however, construct meanings just as they please; othering is subject to the circumstances directly transmitted from the past and the circumstances directly influenced by particular spatio-temporal contexts. What emerges is a historically-specific mode of representing Yugoslavia, what Susan Sontag called "meta-code" or "human universal" for creating shared meanings ${ }^{(8)}$, or what John Ruggie called "the paradigmatic form of reality."(9)

Ruggie's term is particularly suggestive, in that any representation of Yugoslavia constructed through the intellectual debate is neither static nor exceeding temporality; it is, rather, a temporally specific mode of representation. This temporality of representation could be designated by revisiting the conception of balkanism put forward by Todorova, which has been perhaps the most dominant mode of constructing representations of Yugoslavia. Balkanism is an independent and particularistic western rhetorical paradigm for perceiving and understanding the Balkan region ${ }^{(10)}$. The basic discourses of the Balkans have been historically articulated in the West, offering "ideal type constructions

(6) Campbell 1998, ix.

(7) It is important to note here that othering is not entirely dependent upon the practices of outsiders; the categories and knowledge of others are also reproduced by the others themselves (see Todorova 1997, Chapter 2). The meanings, representations, and otherness are mutually constructed by external othering and internal selfdesignation. Although this internal reproduction indeed calls for attention, this article limits its focus specifically on the othering of the object carried out by the subject.

(8) Sontag 1986, 14.

(9) Ruggie 1993, 145-6.

(10) Todorova 1994, 454. Clearly, the conceptualization of balkanism owes much to Said's work on orientalism. However, it needs to be elucidated that, whilst both balkanism and orientalism share terms and episteme of making 'other,' these are fundamentally different, in that "while orientalism is dealing with a difference between (imputed) types, balkanism treats the differences within one type" (Todorova 1997: 19). 
of the spatial, temporal, and ethical dimensions of identity" of not only the Balkans itself but also the West, on the basis of "radically different Others and Selves." ${ }^{(11)}$ The balkanization discourses often involve with three closely-correlated constructions: the spatial (where is the Balkans?): the temporal (who are the Balkans?): and the ethical (what responsibility does the West have to the Balkans?). Whilst the discursive manoeuvre (the spatial, temporal, and ethical construction) exceeds temporality, a representation emerging out of discursive practices of a given period of time is different from the one constructed within another temporal setting. The eighteenth-century representation of the Balkans was based on orientalist fascination coupled with passion for the classical Greek humanism and antiquity, which articulated a rather positive perception of the Balkans as a successor of the old tradition ${ }^{(12)}$. During the nineteenth century, however, the religious dichotomy between Christian and Muslim entered into the political and cultural vocabulary of western intellectuals, such that "the opposition was phrased as nations eager to develop along the path of European progress against a backward traditionalist polity." ${ }^{(13)}$ Within this rhetorical structure, the Ottoman occupied Balkans was perceived with rather negative connotations-ignorant, simplistic, without education and enlightenment, being far from civilization et cetera ${ }^{(14)}$. The quality of twentieth-century perception of the Balkans was further deviated towards negative representations- - $f i l t h$, passivity, unreliability, misogyny, propensity for intrigue, insincerity, opportunism, laziness, superstitiousness, lethargy, sluggishness, inefficiency, incompetent bureaucracy ... cruelty, boorishness, instability, and unpredictability." ${ }^{(15)}$ These representations of the Balkans share the epistemological manner of discursive construction (spatial, temporal, and ethical question), but the outcomes differ from one another. Hence any given representation is paradigmatic.

This quality of representational temporality evokes a condition imperative to problematize what makes the construction of temporally specific representations possible, because it is flawed to naively presume "the epistemological security of an extradiscursive domain, a narrative-free and interpreterless zone of reference, to stabilize particular understandings via their correspondence to 'facts." "(16) More precisely, the question here is what representation of Yugoslavia has emerged from the postCold War conceptualization of new wars vis-à-vis reorganizing the self/other relationship, and how a cosmopolitan solution has been justified as the appropriate way to deal with Yugoslavia.

\section{New wars and cosmopolitan solution}

International politics in the post-Cold War era is said to have been marked by what Fukuyama called "the end of history." ${ }^{(17)}$ The ideological homogenization and politico-social transformation do not however come without struggles. The era has also been marked by "new forms of violence, [which

\footnotetext{
(11) Hansen 2006, 95.

(12) Todorova 1997, 62-70.

(13) Ibid., 70.

(14) Ibid., 77.

(15) Ibid., 119.

(16) Campbell 1998, 43.

(17) Fukuyama 1992
} 
are] most often understood in terms of 'ethnic' and 'nationalist' conflicts." The Yugoslav conflict has been regarded as "the most bewildering manifestation of this larger phenomenon." ${ }^{(18)}$ Among the magnum opus ${ }^{(19)}$, Mary Kaldor's new wars thesis (1992) particularly exhibits a comprehensive understanding of new forms of violence, not only offering us the characteristics of contemporary warfare, but also contextualizing the warfare into the post-Cold War globalized international relations, and proposing a cosmopolitan solution as the appropriate way to deal with wars.

The new wars thesis is a mode of accounting for seemingly incomprehensible violence witnessed in Yugoslavia. By problematizing new forms of violence, and by informing three distinctive characteristics of contemporary warfare, (identity politics, decentralization and privatization of violence, and globalized war political economy), the thesis has made perceptible the relationship between identity, violence and the political. The remarkable quality of the thesis is not limited to its characterization of new forms of warfare ${ }^{(20)}$; its significance also lies in its problematization of the conventional nature and scope of knowledge about identity, violence and the political. A problematization is something that "has made possible the transformations of the difficulties and obstacles of a practice into a general problem for which one proposes diverse practical solutions." ${ }^{(21)}$ It "develops the conditions in which possible responses can be given; it defines the elements that will constitute what the different solutions attempt to respond to."(22) The difficulties and obstacles of dealing with new wars were that violence of such wars had been "incomprehensible from a standard strategic calculus" and had exposed "the shortcomings of conventional understanding of 'intra-state' versus 'inter-state' violence."(23) That is to say, the problematization of contemporary warfare involves de-legitimization of norms and practices developed on the basis of the Westphalian statist principles. And the Yugoslav conflict came to represent a seemingly intractable problem for such principles. As the conventional solutions for wars were ostracized as irrelevant, a concern with an alternative solution necessarily emerged. Within such a discursive realm of problematization, according to Kaldor, a cosmopolitan project, that is to say the construction of a global civil society, becomes possible and even appropriate, because it exceeds the exclusive identity politics in war-torn societies and the double-standard "military humanism" ${ }^{(24)}$ of current conflict management. Simply put, the problematization of new forms of war has produced the necessary conditions for proposing a new order of solutions. The cosmopolitan solution was made possible by the way wars were perceived and defined in the first place.

(18) Campbell 1998, 3.

(19) Dragovic-Soso (2008) offers us a very comprehensive review of the enormous array of literature by introducing categories of causality of the Yugoslav conflict.

(20) Kaldor's claim on the new-ness of contemporary warfare has been widely discussed within and outside the Anglo-American academia, and not surprisingly it comes with criticisms. For example, Newman (2004: 173) argues that the distinction between wars of earlier times and what Kaldor defines as new wars is exaggerated and "in some instances does not stand up to scrutiny, especially when drawing upon historical material." In particular, contemporary forms of organized violence, including genocide, ethnic cleansing, and internal displacement that specifically target civilians, do not reflect, as Newman criticizes, new patterns "in terms of actors, objectives, spatial context, human impact, and the political economy and social structure of conflict" (Ibid).

(21) Foucault 1984, 389.

(22) Ibid.

(23) Campbell 1998, 3.

(24) Chomsky 1999 
Because our perception of wars has been altered, the conventional solutions for wars are no longer appropriate. "At the beginning of the 1990s," Kaldor writes, "there was a lot of optimism about the possibilities for solving global problems, particularly wars," and consequently, with the publication of An Agenda for Peace ${ }^{(25)}$, "the number of UN peacekeeping operations increased dramatically ... Mandates were also strengthened," as exemplified by the Bosnian case, and the scope of multilateral peacekeeping operations was expanded to accommodate regional and local organizations ${ }^{(26)}$. In Bosnia, the UN-led peacekeeping operation was assigned, in cooperation with regional and local agencies including NATO, the EU (then EC), and the local Bosnian law enforcement agencies, to not only observe the implementation of the Peace Agreement of 1995, but also work for issues relating to humanitarian relief and refugees, human rights, demining, elections, and rehabilitation of infrastructure and economic reconstruction $^{(27)}$. This wide range of activities marks a stark contrast to the activities of peacekeeping operations during the Cold War, in that, for instance, the mandate of the United Nations Military Observer Group in India and Pakistan (UNMOGIP) established in 1949 defines the role of the operation as merely "to observe, to the extent possible, developments pertaining to the strict observance of the ceasefire" and "to report thereon to the Secretary-General."(28)

Despite the extended scope of authority and the expanded array of activities, which have transformed the limited peacekeeping operations into rather 'humanitarian' interventions, the peacekeeping operation in Bosnia is said to have been shamed and humiliated in several ways ${ }^{(29)}$; it failed to secure the safe haven of Srebrenica; it conferred public legitimacy on those who were later considered war criminals_- "the paradox [was] that international negotiators were ... shaking hands with Karadzic and Mladic, both of whom had ... been named ... as war criminals"(30); it made possible the re-emergence of exclusivist politics by implementing territorial partition which reinforced identity-based segregations; and it overestimated the peaceful intention of warring parties, whose power was largely dependent not on consent, but on creating fear and instigating hatred of the other. Highlighting these problems and challenges that emerged from the Bosnian case certainly endorses Kaldor's claim that the experience of humanitarian intervention has so far been at best frustrating and at worst a failure ${ }^{(31)}$. This has been attributed to a fundamental lack of understanding of new forms of war. She writes,

... the most important explanation [of the failure] is misperception, the persistence of inherited ways of thinking about organized violence, the inability to understand the character and logic of the new warfare. One response to the new wars has been to treat them as Clausewitzean wars in which the

\footnotetext{
(25) Boutros-Ghali 1992

(26) Kaldor 1992, 119-20.

(27) United Nations Mission in Bosnia and Herzegovina (UNMIBH) Mandate, available at http://www.un.org/en/ peacekeeping/missions/past/unmibh/mandate.html

(28) United Nations Military Observer Group in India and Pakistan (UNMOGIP) Mandate, available at http:// www.un.org/en/peacekeeping/missions/unmogip/mandate.shtml

(29) Peacekeeping operations have met numerous challenges not only in Bosnia. For instance, in Congo, the operation was criticized as 'humanitarian catastrophes,' and in Somalia, the intervention was quickly abandoned when it faced the counter-insurgency.

(30) Kaldor 1992, 126

(31) Ibid., 120.
} 
warring parties are states, or if not states, groups with a claim to statehood. Many of the terms used such as 'intervention,' 'peacekeeping,' 'peace-enforcement,' 'sovereignty,' 'civil war,' are drawn from conceptions of the nation-state and of modern war that are not only difficult to apply in the current context, but may actually pose an obstacle to appropriate action. Other response is fatalistic. Because the wars cannot be understood in traditional terms, they are thought to represent a reversion to primitivism or anarchy ... In other words, wars are treated as natural disasters ... ${ }^{(32)}$

Such criticisms are not entirely unique to Kaldor. William Shawcross concedes that humanitarian intervention may sometimes do more harm than good by prolonging a conflict ${ }^{(33)}$; Bruce Jones shows that the lack of integrative strategy, the intransigence of the warring parties, and the weak support from the international community have caused the failure ${ }^{(34)}$; and Nicholas Wheeler points out that the inaction of the international community and the lack of coherent strategy are indeed symptomatic of failures on the part of the international community to address the problems and the challenges posed by contemporary wars ${ }^{(35)}$.

My reading of these criticisms goes even further into a normative realm. What I am educing here from Kaldor's and others' criticisms of international community is that, whilst the Clausewitzean and fatalist solution to conflicts may render a mode of 'politics,' that is to say a set of practices and institutions through which orders, rules and customaries are created and organized, such solutions lack 'the political,' that is, a concern for how a war-torn society is and ought to be instituted. For instance, the mandate and the UN resolutions for Bosnia specify the required set of practices essential for implementing the peace agreement and identify the necessary institutions for carrying out such practices. And yet, nowhere in these documents is found an expression of a particular structure of the relationship among local communities and local populations, nor the politics of inclusion as an alternative to the politics of exclusion exercised during the conflict. Although terms such as 'peace,' 'democracy' and 'human rights' are used a number of times in these documents, these terms merely obscure 'the political,' and only speak for an ideology for reconstructing the war-torn society.

Kaldor's answer to the lack of 'the political' is the cosmopolitan political mobilization through the construction of global civil society ${ }^{(36)}$. The cosmopolitan political mobilization as an alternative form of 'the political' is apparently founded upon Hannah Arendt's conception of 'the political': the political as a space of freedom and public deliberation, which is based on the idea of active citizenship, and which is instituted via civic engagement and collective deliberation about all matters touching upon a community ${ }^{(37)}$. For Arendt, civic engagement and collective deliberation require the act of persuasion

(32) Ibid.

(33) Shawcross 1999

(34) Jones 2001

(35) Wheeler 2000

(36) Again, it needs to be noted that, as much as the criticisms of the conventional solutions to wars are not entirely unique to Kaldor, so is the endorsement of cosmopolitanism as an alternative. In the 1990s, following the eclipse of the communist regimes, cosmopolitanism was prospering as one of the modes of re-organizing the international political landscape. The advocates of implementing cosmopolitanism to and materializing its ideal in an international arena includes Giddens (1994), Held (1995, 2004), Beck $(1994,1997)$, Habermas (1998, 2001), Archibugi (2003), Chandler (2003). 
and dissuasion through which citizens would equip themselves with a capacity to think representative${ }{ }^{(38)}$. Kaldor transposes Arendt's notion of community onto 'the international. ${ }^{(39)}$ Following Arendt's conception, Kaldor endorses cosmopolitanism by defining it as "a positive political vision, embracing tolerance, multiculturalism, civility and democracy, and to a more legalistic respect for certain overriding universal principles which should guide political communities at various levels, including the global level." ${ }^{(40)}$ And a society is and ought to be instituted on the basis of three principles; "a strategy of capturing "heart and minds" "as opposed to "the strategy of sowing "fear and hate": "a politics of inclusion" as an alternative to the politics of exclusion: and "respect for international principles and legal norms" in opposition to "the criminality of the warlords." ${ }^{(41)}$ The global civil society based on these principles is said to provide a global platform, wherein new wars are resolved through negotiation at various levels ${ }^{(42)}$. The rationale behind such a proposal is as follows; the central issue for materializing cosmopolitan practices is to facilitate negotiations, or collective deliberation in Arendt's term, among diverse interest groups, such that the issue of representation becomes a mere precondition which will be resolved once a global platform for negotiations is firmly established. Hence, participation in a global civil society means an opportunity for deliberation, wherein "genuinely free conversation, a rational critical dialogue" ${ }^{(43)}$ will be facilitated, so much so that it becomes possible to connect with other like-minded individuals, or to discuss matters with the opposition. The global civil society, with its accessibility, openness and inclusive debates, transforms individuals into a "Hegelian universal class" who are more likely to act "in the interests of the human community." ${ }^{(44)}$ Consequently, it will allow us to go beyond violent forms of managing global affairs, and its politics of inclusion will eventually result in a unified world without an outside.

\section{3 'The political' reconsidered: Reinforcement of the self/other relationship}

Today, Kaldor's and others' criticisms of the failure of the international community in dealing with wars of the 1990s may have lost their radical distinctiveness and become almost cliché. And yet, the normative quality of these criticisms and subsequent cosmopolitan proposals, which attempt to reconfigure our conviction of ethics, morality, and the political, still calls for judgement. For one thing, such

(37) Arendt 2005, 108. See also Calhoun et al. 1997.

(38) Ibid., 14-5.

(39) In my view, such a simple transposition is problematic. Whilst Arendt's notion of 'community' primarily supposes internal community within a state, Kaldor's idea of 'community' expands its scope to the international level. Can such a simple transfer be made? Is an international community organized fundamentally in the same way an internal community is organized? In addition, the inherent notion of an international 'community' is also problematic, as it presupposes a boundary in and of itself, and implies the existence of obligations, duties and actions, which are often based on liberal principles. Therefore, civic engagement in international community is inherently conditional, as that, in order to engage in discussion and deliberation in international community, actors ought to satisfy particular requirements, that is to say the respect for the liberal values.

(40) Kaldor 1992, 123.

(41) Ibid., 121.

(42) Kaldor 2003

(43) Kaldor 2003, 108.

(44) Ibid. 
attempts necessarily evoke a question of the (im)possibility of universal ethics and morality. For another, a cosmopolitan politics of inclusion does not literally mean an all-inclusive form of the political, but presupposes a boundary in and of itself. That said, what is necessary now is to go beyond the empirical and into a realm of the theoretical, by reconsidering the discursive conditions that have made possible the reconfiguration of our conviction of ethics, morality, and the political.

Whilst it may seem as inclusive as it proposes ${ }^{(45)}$, the idea of cosmopolitan global society, more precisely ethics, morality and the political behind such an idea, is problematic, particularly if it is contextualized in the Yugoslav case. The problem lies in its understanding of the self/other relationship. If the cosmopolitan alternative is to provide a space for the politics of inclusion, and for the eventual construction of a unified world without an outside, does it mean that the West's question of self/other relationship, which has been defined through balkanization discourses, will be (or has already been) cast aside, and that the once acceptable paradigmatic form of representing Yugoslavia that was based on othering will be (or has already been) transformed? If the development of a cosmopolitan project, although not yet fully materialized, means that balkanization discourses have become anachronistic, what kind of alternative mode of representing Yugoslavia (and the former Yugoslav states) is there to be identified?

Indeed, cosmopolitanism and balkanism seemingly constitute a banal opposition of understanding the politics of inclusion and exclusion, of making commonality and otherness. Having said that, one might interpret Kaldor's criticism of the failure of international community as a polemical statement against the long-held balkanist tradition in the West ${ }^{(46)}$. How polemical? Perhaps Slavenka Drakulic's words give us an explicit idea. The Croatian novelist and writer, who has written for various media that have also published a number of Kaldor's works ${ }^{(47)}$, and who, judging from her works, shares a concern similar to Kaldor's, writes,

So we all get used to it. I understand now that nothing but "otherness" killed Jews, and it began with naming them, by reducing them to the other. Then everything became possible. Even the worst

(45) It is not difficult to imagine, however, that a cosmopolitan project, not limited to Kaldor's but also others,' has met various criticisms. For one thing, although its feasibility is still not yet properly addressable as it is an ongoing project and as the majority of its debate is written and spoken in the future tense, the overfamiliar criticism is that a cosmopolitan project is at best idealistic and at worst utopian. Kaldor herself once admitted that "some of her ideas of international security sound utopian ..." but insisted, "the world needs utopians" (Tran 2008, an interview with Kaldor). For another, a cosmopolitan project as an alternative solution to wars does not address the problematic reality of the West having a double-standard in implementing such a project. That is to say, whilst the necessity of implementing cosmopolitan practices into war-torn societies in order to resolve the conflicts and organize a platform for non-violent social and political life has been explicitly warranted, the genocidal practices of the West, for example the NATO bombing of Serbia, the western invasion into Iraq, the Russian attack in Chechnya, and Israeli airstrike to the West Bank and Lebanon, have been left out from the discussion. As Martin Shaw aptly points out, "reconstructing local legitimacy, and indeed constructing global legitimacy, ultimately requires Western and other major states to repudiate war as a solution, and to dismantle their potentially genocidal military structures which provide a framework of legitimacy for all the new warriors" (Shaw 2000: 179).

(46) Such an interpretation is not my own. Here I simply suggest a seemingly correct reading of Kaldor's argument in relation to balkanism. I believe, however, it is also inherently hegemonic in assuming that cosmopolitan values are universally shared and/or desired.

(47) These include The Nation magazine, Open Democracy, the New York Review of Books, and the Guardian. 
atrocities like concentration camps or the slaughtering of civilians in Croatia or Bosnia. For Serbians, as for Germans, they are all others, not-us ... For Europe, the "other" is the lawless "Balkans" they pretend not to understand. For the USA it's more or less a "European problem" why should they bother with the screams of thousands of people being bombed or simply dying of hunger, when the screams can hardly be heard? Let Europe do something, aren't they working the land next to the barbed wire ? $^{(48)}$

The classification of Yugoslavia as 'not-us,' hence 'others,' was a fundamental principle of releasing the West "from any responsibility or empathy." ${ }^{(49)}$ The alleged otherness of Yugoslavia has been used to legitimize the inaction and 'military humanism' of the West. Whilst, in reality, the misperception on the outsiders' part in understanding the nature of the Yugoslav conflict might have caused the subsequent failure of intervention, the fundamental epistemological issue, although not readily apparent, was the continued othering of Yugoslavia. Thus, one might argue that Kaldor's criticism of international community and her de-legitimization of international politics based on the Westphalian principles have derived from her concern for the constituted otherness of Yugoslavia. For such an argument, the cosmopolitan global civil society seemingly represents a new form of the political that surmounts the problems derived from othering and transforms the politics of exclusion into that of inclusion.

Was such a cosmopolitan attempt successful? It was, in my view, somewhat of a disappointment precisely on two grounds. First, the characterization of the Yugoslav conflict as an archetype of new wars was not particularly helpful to alter balkanist representations; instead it has reinforced to a certain extent the negative connotations of Yugoslavia as the other. And such negative connotations were repeatedly reproduced in academia, in political circles, and in the media, during the conflict. Second, the cosmopolitan solution was not as inclusive as it proposed itself to be, in form of that its inclusiveness was dependent upon certain conditions derived from a particular ethics, morality, and ideal type of how society ought to be instituted. Because ethics, morality, and ideal type of society are not singular but plural conceptions, linking them to the cosmopolitan politics of collective deliberation simply means an exclusion of something unethical/immoral/defective from the very politics of the cosmopolitan solution. Hence, though the political within the global civil society might be based on freedom and public deliberation, the antagonistic dichotomies are inherent features of the political of such a global platform.

To further clarify, the point of departure is to acknowledge that the conception of new wars in fact goes beyond a mere description of the new-ness of wars. It is simultaneously an act of naming, thus a categorical imperative for comprehending the complexity of the Yugoslav conflict, which evokes constructive power of intellectual cognitive process in making meanings and representations of the subject matter. As much as the prototypes of groups of people derived from the balkanization discourses are not value free, neither are the characteristic forms of representation that the conception of new wars manifests.

\footnotetext{
(48) Drakulic 1993, 143-6.

(49) Todorova 1997, 185.
} 
Identity politics, one of the constituents of the new-ness of wars, for instance, is defined as being "fragmentative, backward-looking and exclusive," which is based on and acquired through "insecurity" and "rekindled fear of those with different labels." ${ }^{(50)}$ And it often arises out of "the disintegration or erosion of ... centralized, authoritarian states." ${ }^{(51)}$ If identity politics is as defined, it simultaneously recalls a possibility or even a necessity of a form of politics that is not fragmentative, but forwardlooking and inclusive, and does not evoke either insecurity or fear. The proposed ideal type as opposed to identity politics is a cosmopolitan consensual form of politics ${ }^{(52)}$, which is founded upon Arendt's idea of the political ${ }^{(53)}$, and expanded on the basis of Giddens' conception of 'post-traditional society' wherein 'life politics ${ }^{\text {(54) }}$ accompanied with dialogic democracy ${ }^{(55)}$ would exceed narrowly defined identities and group-specific interests. The presentation of ideal type as opposed to the exclusive ethnicization of politics in Yugoslavia draws a sharp distinction between 'civic' and 'ethnic' forms of organizing society, with the former often regarded as being central to the West and the latter being discriminative of Yugoslavia.

Surely, the effect of such a distinction presupposes a linear political modernization and development, whereby a hierarchy is constructed with the civic West at the top. Here, the rhetoric of categorical imperative of new wars is rekindled with the old balkanization discourses, and permitted to manifest the indiscriminate generalization of the conflict, the seemingly static representation of the Yugoslav as ethnic nationalists, and the relative identification of civic West. The central achievement of compartmentalizing Yugoslav conflict into the new-war category is to reduce the complexity of the conflict into a few visible prominent attributes, and subsequently to stabilize the particular representations. Such representations had been repeatedly reproduced in Anglo-American academia, in political circles, and in the media, through which the negative imagery of the conflict was further broadened. "The history of the region is quite warlike" ${ }^{(56)}$; the helplessness of the crisis and violence was simply because "it's the Balkans" ${ }^{(57)}$; the war is "about the land ... and, of course, ethnic hatred" ${ }^{(58)}$; and, "extreme nationalism in the former Yugoslavia had not been only a matter of imagining allegedly 'primordial' communities, but rather of making existing heterogeneous ones unimaginable."(59) These representational reproductions have transformed the phenomena, or appearance in Nietzsche's term, of new wars into the essence of Yugoslavia. On this matter, Nietzsche writes,

The reputation, name, and appearance, the usual measure and weight of a thing, what it counts for-originally almost always wrong and arbitrary ... — all this grows from generation unto generation, merely because people believe in it, until it gradually grows to be part of the thing and turns

\footnotetext{
(50) Kaldor 1992, 81.

(51) Ibid.

(52) Kaldor 2003, 108.

(53) Arendt 1977 and 2005

(54) Giddens 1991, 214.

(55) Giddens 1994, 93.

(56) Posen 1993,114.

(57) Rifkind 1995

(58) Holbrook, quoted in Rosenberger 1995.

(59) Hayden 1996, 783.
} 
into its very body. What at first was appearance becomes in the end, almost invariably, the essence and is effective as $\operatorname{such}^{(60)}$.

The essentialization of mere appearances and the manifestation of a new paradigmatic form of Yugoslav representation that effectively reinforces the otherness of Yugoslavia are fundamental for making the cosmopolitan solution possible. The assumed otherness and inferiority of Yugoslavia constitutes a ground for rationalizing a new 'civilizing' mission under the guise of global civil society with its seemingly universal ethics and morality. Although I suspect that Kaldor and other advocates of cosmopolitan forms of politics intend to reintroduce the segmentation of people according to the extent of civility, democracy or stability of their societies, the horizontal line of inclusion that is manifested by the cosmopolitan solution is contingent upon the vertical line of exclusion based on a hierarchy between civic and ethnic form of politico-social organization. Simply put, the political of cosmopolitanism is dependent upon its assumed relative superiority. The rhetoric of vindicating this superiority is understood in twofold. Our-of course 'our' signifies primarily 'the western'—social reality is that we are now entering into a second stage of modernity, whereby the reorganization of traditional politics, including ethnically based identity politics, is unavoidable, because individuals, not collective actors such as states, are now brought to the center of politics ${ }^{(61)}$; and the individual's political will is best to be realized through deliberative forms of politics, which the cosmopolitan global civil society promises to provide ${ }^{(62)}$. The indispensable achievement of this rhetoric is that it has transformed Kantian cosmopolitanism, fundamentally an intellectual ethos, into the existing form of political solidarity, vis-à-vis creating the link between ethics/morality/ideal type and politics. Cosmopolitan ethics defines individual's identity association in opposition to those identities based on specific ethnicities, cultures, or religions. And the individual is understood as the very agency to possess moral values. Hence, they are all united via similar moral precepts; morality is universal. There is, therefore, a possibility of developing universal political platform, principles, norms, and guidelines, which are applicable regardless of social or cultural differences.

Paradoxically, but not surprisingly, the individualism of cosmopolitan ethics and the universality of morality are problematic ideas. If the individual is the ultimate point of reference for ethics, it is not necessarily the case that his/her self-identification ought to exceed boundaries between particular communities; the individual is, after all, a free agent, and could choose whichever community, global or local, as the basis for self-identification and for an articulation of ethics. The affirmation of a universal consensus on morality therefore arguably fails to acknowledge the possibility of antagonism between individual values. Simply put, ethics and morality are not singular but plural conceptions. As Walker accurately points out, although ethics and morality "come to be understood as an achieved body of principles, norms and rules already codified in texts and tradition," they are not "a repository of principles awaiting application; it is an ongoing historical practice. ${ }^{\left({ }^{(63)}\right.}$ And this historicity of ethics

\footnotetext{
(60) Nietzsche, cited in Bakic-Hayden 1995, 917.

(61) Beck 1994, 22. Giddens 1994, 7.

(62) Kaldor 2003, 108.

(63) Walker 1993, 50-1.
} 
and morality evokes a specific space and condition for speaking about and implementing them. The western ethics and morality, for instance, are only ethical and moral within the western context, and outside of it exists a possibility of different ethics and morality. The advocates of the cosmopolitan global civil society as a solution for new wars, as unconscious as they may be, universalize a particular set of values and impose them under the guise of universal morality. Instead of accurately acknowledging that there are other modes of comprehending and constituting ethics, morality and the political, the advocates of the cosmopolitan solution falls in the fallacy of the possibility of all-inclusive politics and a unified world without an outside. The political of, not within, the cosmopolitan global civil society is founded upon inevitable antagonisms and eliminations of what is considered as unethical, immoral, and defective. That said, the cosmopolitan idea of the political is at best idealistic and at worst deceptive, as it simply assumes that cosmopolitan values are universally shared and desired, whilst in fact there are other sets of values that are shared and desired.

The existential of outside, the others, is undeniable, simply because any ideal type provokes an opposition as its relative reference point. My argument here is indeed a reflection of the Derridean concept of a 'constitutive outside.' Derrida writes,

They do not exist as an entity; it does not exist, before this declaration, not as such. If it gives birth to itself, as free and independent subject, as possible signer, this can only hold in the act of the signature. The signature invents the signer. This signer can only authorize him—or himself, to sign once he or she has come to the end ... if one can say this, of his or her own signature, in a sort of fabulous retroactivity ${ }^{(64)}$.

Any creation and justification of ideal type —and indeed an identity associated to the ideal-implies the establishment of a difference, "which is often constructed on the basis of a hierarchy." ${ }^{(65)}$ Therefore, the outside is not only 'out there,' but also an absolute requirement for an existential question of the self, and for ethics, morality, and ideal type that 'we' consider just. That said, the proposed inclusiveness of the cosmopolitan global civil society is in fact conditional. Unless complying with the western ethics, morality, and ideal type of the political, others are ostracized from the collective deliberation of the cosmopolitan global platform for resolving violence.

\section{Conclusion}

The new wars thesis has altered the way in which we understand violence, identity and politics in the post-Cold War international relations, and has offered a powerful criticism of the Clausewitzean conception of war and the Westphalian mode of dealing with it. These achievements of the thesis are undoubtedly significant, but this paper has offered an alternative reading of the thesis, suggesting that it has also played an essential part in reconfiguring our conviction of ethics, morality, and the political.

\footnotetext{
(64) Derrida 1976, 10.

(65) Mouffe 2005, 15.
} 
My problematization of Kaldor's new wars thesis brings to the fore the discursive construction of Yugoslavia as an embodiment of the characteristics of new wars, which reinforces the question of self/ other relationship. As much as the long-standing balkanism was essential as a rhetorical paradigm, in perceiving Yugoslavia, this paper has argued that the new wars thesis has effectively constructed another paradigm of representing Yugoslavia, and importantly, through the reconfiguration of our ethics, morality and the political, the thesis has also rearticulated, perhaps in a manner that is not readily apparent, the relative superiority of the civic West, by reifying the polarity of heterogeneous domains, such as West and non-West, us and them, civic and ethnic, and ideal and defective.

\section{Bibliography}

Archibugi, Daniele (ed.) (2003) Debating Cosmopolitics, London: Verso

Archibugi, Daniele, and Held, David (eds.) (1995) Cosmopolitan Democracy: An Agenda for a New World Order, Cambridge: Polity Press

Arendt, Hannah (1977) Between Past and Future: Eight Exercises in Political Thought, $2^{\text {nd }}$ ed., New York: Penguin Books (2005) The Promise of Politics, J. Kohn (ed.), New York: Schocken Books

Bakic-Hayden, Milica (1995) "Nesting Orientalisms: The Case of Former Yugoslavia", Slavic Review, Vol. 54, No. 4

Beck, Ulrich (1994) "The Reinvention of Politics: Towards a Theory of Reflexive Modernization”, in U. Beck, A. Giddens, and S. Lash (eds.), Reflexive Modernization, Cambridge: Polity Press

(1997) The Reinvention of Politics: Rethinking Modernity in the Global Social Order, Cambridge: Polity Press

Blair, Tony (24 ${ }^{\text {th }}$ April, 1999) "Doctrine of the International Community", speech by Tony Blair at the Economic Club, Chicago, available at http://www.pm.gov.uk/output/Page1297.asp (23/01/2013)

Boutros-Ghali, Boutros (1992) "An Agenda for Peace: Preventive diplomacy, peacemaking and peace-keeping", Report of the Secretary-General pursuant to the statement adopted by the Summit Meeting of the Security council on $31^{\text {st }}$ January 1992, New York: the United Nations

Calhoun, Craig and McGowan, John (eds.) (1997) Hannah Arendt and the Meaning of Politics, Minneapolis: University of Minnesota Press

Campbell, David (1998) National Deconstruction: Violence, Identity, and Justice in Bosnia, Minneapolis: University of Minnesota Press

Chandler, David (2003) "New Rights for Old? Cosmopolitan Citizenship and the Critique of State Sovereignty", Political Studies, Vol. 51, No. 2

Chomsky, Noam (1999) The New Military Humanism: Lessons from Kosovo, London: Pluto

Clinton, Bill (27th November, 1995) "Speech on Bosnia", available at http://edition.cnn.com/US/9511/bosnia_ speech/speech.html (15/01/2013)

Creveld, Martin van (1991) The Transformation of War: The Most Radical Reinterpretation of Armed Conflict since Clausewitz, New York: The Free Press

Derrida, Jacques (1976) “Declarations of Independence”, T. Keenan and T. Pepper (trans.) New Political Science, Vol. 15

Dragovic-Soso, Jasna (2003) "Intellectuals and the Collapse of Yugoslavia: The End of the Yugoslav Writers' Union”, in D. Djokic (ed.), Yugoslavism, London: C Hurst \& Co Publishers Ltd.

(2008) "Why Did Yugoslavia Disintegrate? An Overview of Contending Explanations", in L.J. Cohen and J. Dragovic-Soso (eds.), State Collapse in South Eastern Europe: New Perspectives on Yugoslavia's Disintegration, West Lafayette, Indiana: Purdue University Press

Drakulic, Slavenka (1993) The Balkan Express: Fragments from the Other Side of the War, New York: W.W. Norton and Company

Drew, Andrea J. and Mohamedou, Mohammad-Mahmoud Ould (2007) "Empowered Groups, Tested Laws, and Policy Options: Report on an Interdisciplinary Seminar on Transnational and Non-State Armed Groups", Organized by the Program on Humanitarian Policy and Conflict Research at Harvard University and the Graduate Institute of International Studies in Geneva in cooperation with the Radcliffe Institute for Advanced 
Study, March 8-10, 2007, available at http://www.tagsproject.org/_data/global/images/Report_Empowered_ Groups_Nov2007.pdf (26/01/2013)

Foucault, Michel (1984) "Polemics, Politics, and Problematizations: An Interview with Michel Foucault", in Paul Rabinow (ed.), The Foucault Reader, New York: Pantheon Books

Fukuyama, Francis (1992) The End of History and the Last Man, New York: Free Press

Giddens, Anthony (1991) Modernity and Self Identity, Cambridge: Polity Press (1994) Beyond Left and Right, Cambridge: Polity Press

Habermas, Jurgen (1998) Between Facts and Norms, Cambridge, MA: MIT Press (2001) The Postnational Constellation, Cambridge, MA: MIT Press

Hansen, Lene (2006) Security as Practice: Discourse Analysis and the Bosnian War, Abingdon: Routledge

Hayden, Robert M. (1996) "Imagined Communities and Real Victims: Self-Determination and Ethnic Cleansing in Yugoslavia", American Ethnologist, Vol. 23, No. 4

Held, David (1995) Democracy and the Global Order, Cambridge: Polity Press (2004) Global Covenant: The Social Democratic Alternative to the Washington Consensus, Cambridge: Polity Press

Jay, Martin (1992) "Of Plots, Witnesses, and Judgement”, in S. Friedlander (ed.), Probing the Limits of Representation: Nazism and the "Final Solution", Cambridge: Harvard University Press

Jones, Bruce D. (2001) Peacemaking in Rwanda: The Dynamics of Failure, New York: Lynne Rienner Publishers Kaldor, Mary (1992) New \& Old Wars: Organized Violence in a Global Era, Cambridge: Polity Press (2003) Global Civil Society: An Answer to War, Cambridge: Polity Press

Mouffe, Chantal (2005) On The Political, New York: Routledge

Munkler, Herfried (2005) New Wars, Malden MA: Polity Press

Newman, Edward (2004) “The 'New Wars' Debate: A Historical Perspective is Needed", Security Dialogue, Vol. 35 , No. 2

Posen, Barry (1993) "The Security Dilemma and Ethnic War", in M. Brown (ed.), Ethnic Conflict and International Security, Princeton, NJ: Princeton University Press

Rifkind, Malcolm (6 ${ }^{\text {th }}$ February, 1995) "WWII Hell Relived", Los Angeles Times

Rosenberger, Chandler (25 ${ }^{\text {th }}$ September, 1995) "More to Bosnia than 'Ethnic Hatreds"”, Wall Street Journal

Ruggie, John Gerard (1993) "Territoriality and Beyond: Problematizing Modernity in International Relations", International Organization, Vol. 47, No. 1

Said, Edward (1979) Orientalism, New York: Random House, Inc.

Shaw, Martin (2000) "The contemporary mode of warfare? Mary Kaldor's theory of new wars", Review of International Political Economy, Vol. 7, No. 1

Shawcross, William (1999) Deliver Us From Evil, Bloomsbury: Simon \& Schuster

Sontag, Susan (1986) Against Interpretation and Other Essays, New York: Octagon Books

Todorova, Maria (1994) “The Balkans: From Discovery to Invention”, Slavic Review, Vol. 52, No. 2 (1997) Imagining the Balkans, Oxford: Oxford University Press (2004) Balkan Identities: Nation and Memory, London: C. Hurst \& Co. Publishers Ltd.

Tran, Mark (1 $1^{\text {st }}$ April, 2008) "The international community makes terrible mess wherever it goes" (An interview with Mary Kaldor), Guardian, available at http://www.guardian.co.uk/world/2008/apr/01/mary.kaldor. interview $(15 / 01 / 2013)$

United Nations Military Observer Group in India and Pakistan (UNMOGIP) Mandate, available at http://www. un.org/en/peacekeeping/missions/unmogip/mandate.shtml (26/01/2013)

United Nations Mission in Bosnia Herzegovina (UNMIBH) Mandate, available at http://www.un.org/en/ peacekeeping/missions/past/unmibh/manadate.html (26/01/2013)

Walker, Robert B.J. (1993) Inside/Outside: International Relations as Political Theory, New York: Cambridge University Press

Wheeler, Nicholas J. (2000) Saving Strangers: Humanitarian Intervention in International Society, Oxford: University of Oxford Press

（本論文は，複数のレフェリーによる審査を経て編集委員会が採択した。） 